\title{
Code Banken: op weg naar vertrouwen?
}

Auke de Bos, Henk Edelman, Marlène Jans-van Wieringen en Johan Scheffe

SAMENVATTING Mede naar aanleiding van de kredietcrisis is de Code Banken gepubliceerd. De Code introduceert principes op het gebied van de versterking van de governancestructuur en het risicomanagement binnen banken, het beloningsbeleid van banken en de positie van de aandeelhouders vanuit het perspectief van de maatschappelijke functie van banken. In de jaarverslagen van banken over 2010 dient voor het eerst verantwoording te worden afgelegd over de naleving van de Code Banken. Uit ons onderzoek volgt dat de meeste banken uitgebreid rapporteren over de naleving van de Code Banken. De mededeling over de naleving van de Code Banken is voor verbetering vatbaar, en dat geldt ook voor de informatieverstrekking over de invulling die gegeven is aan de principes. $0 \mathrm{~m}$ dit te bewerkstellingen doen wij een aantal aanbevelingen en hebben wij 'best practices' geïdentificeerd. De banken zijn nu zelf aan zet om hier in de toekomst nog verder invulling aan te geven.

\section{RELEVANTIE VOOR DE PRAKTIJK In de jaarverslagen over 2010 dienen de banken voor het eerst verantwoording af te leggen over de naleving van de Code Banken en te motiveren wanneer een principe niet (volledig) is toegepast volgens het 'pas toe of leg uit'-beginsel. Mede gezien de maatschappelijke belangstelling voor banken is het interessant om vast te stellen hoe de banken invulling geven aan de Code Banken. Wij inventariseren de huidige praktijk, presenteren een aantal 'best practices' en komen met een aantal aanbevelingen.}

\section{Inleiding}

Sinds de kredietcrisis heeft het vertrouwen in de bancaire sector een flinke deuk opgelopen. De sector heeft de afgelopen jaren zowel in Nederland als in het buitenland te maken gehad met faillissementen, overnames en noodingrepen door overheden om grote banken overeind te houden. Deze crisis heeft het vertrouwen in banken flink ondermijnd, want het vertrouwen in een bank is gebaseerd op de gedachte dat zij aan haar betalingsverplichting kan voldoen (Diekman, 2010). Als centraal instituut waar enerzijds spaarders hun spaargeld tegen enig rendement solide kunnen vastzetten en anderzijds investerende partijen gelden kunnen lenen, vervullen banken immers een sleutelpositie in het economisch bestel.

De Tijdelijke Commissie Onderzoek Financieel Stelsel onder leiding van De Wit (2010) onderkent dat de handelwijze van financiële instellingen, waaronder de bankensector, een grote rol speelt in het ontstaan van de crisis. Door de crisis zijn belangrijke tekortkomingen met betrekking tot risicomanagement boven water gekomen. De balans tussen commerciële belangen enerzijds en de daarbij behorende risico's anderzijds is te vaak doorgeslagen naar het eerste.

Volgens Snoep (2011) gaat de maatschappelijke verontwaardiging niet alleen over bonussen, maar ook over het gebrek aan zelfreflectie. Volgens hem houden banken zich te stil in de huidige discussie, terwijl zij zich juist actief met de benodigde cultuurverandering bezig moeten houden om het vertrouwen in de maatschappij te herwinnen.

De Adviescommissie Toekomst Banken, ook wel naar haar voorzitter Commissie Maas genoemd (hierna 'Commissie Maas'), onderschrijft dat de bankensector een rol heeft gespeeld bij de crisis. Het besef van de centrale rol die banken spelen in de maatschappij was steeds meer op de achtergrond geraakt. Banken kenden steeds meer gewicht toe aan de aandeelhouders, die veelal een kortetermijnvisie bezaten. Hierdoor lag de nadruk steeds meer op de winstontwikkeling op korte termijn en was het variabele deel van het inkomen van de bestuurders van banken en het (hoger) bankpersoneel veelal hiervan afhankelijk gemaakt (Adviescommissie Toekomst Banken, 2009).

Het adviesrapport van de Commissie Maas is erop gericht aanbevelingen te doen ter verbetering van het functioneren van de Nederlandse bancaire sector en zo handvatten te bieden voor het herstel van het vertrouwen in de banken. Dat vertrouwen van de consument is door de financiële crisis, ook in Nederland, behoorlijk geschaad. 
Dit artikel beschrijft ons verkennende onderzoek naar de vraag op welke wijze banken verantwoording afleggen over de wijze waarop zij de Code Banken naleven en in hoeverre de (toepassing van de) Code Banken heeft geleid tot meer relevante informatie over het functioneren van banken met als doel het vertrouwen in banken te vergroten. Immers de introductie van de Code Banken kwam mede voort uit druk vanuit de maatschappij. Een transparante verantwoording met betrekking tot de naleving van de Code Banken zou een belangrijke stap kunnen zijn op weg naar het herstel van vertrouwen.

Paragraaf 2 behandelt de relevante wet- en regelgeving en een beschrijving van de totstandkoming van de Code Banken, paragraaf 3 omvat het empirisch onderzoek van de informatievoorziening over de Code Banken en ten slotte trekken wij conclusies en formuleren wij aanbevelingen in paragraaf 4 .

\section{Wet- en regelgeving}

Wij behandelen achtereenvolgens het rapport van de Commissie Maas, de hiervan afgeleide Code Banken, de wettelijke verankering van die Code Banken via het Besluit inhoud jaarverslag banken en de eerste bevindingen van de Monitoring Commissie Code Banken die in 2010 is ingesteld om de naleving van de Code Banken te monitoren.

\subsection{Commissie Maas}

\subsubsection{Rapport Commissie Maas}

Op 7 april 2009 heeft de Commissie Maas haar rapport getiteld 'Naar herstel van vertrouwen' gepresenteerd. De onafhankelijke commissie, waarin onder andere de voormalige CFO's van ING, ABN AMRO en Rabobank zitting hebben, is in november 2008 ingesteld door de Nederlandse Vereniging van Banken (hierna NVB). De commissie is gevraagd om lessen uit de kredietcrisis te trekken en aanbevelingen te doen voor de sector. Directe aanleiding was een hoorzitting met de Tweede Kamer waarin de CEO's van een aantal grote banken uitstraalden dat de bankiers niets fout hadden gedaan en zich dus ook niet hoefden te excuseren voor de gevolgen van de crisis.

De Commissie Maas concentreert zich in haar rapport op de eigen verantwoordelijkheden van banken. In de afwegingen die banken maken, dient het belang van de klant weer centraal te staan. In dat opzicht is volgens de commissie een fundamentele mentaliteitswijziging en heroriëntatie in het bankwezen nodig. De aanbevelingen hebben betrekking op:

- versterking van de governancestructuur en het risicomanagement binnen banken;
- het beloningsbeleid van banken en de positie van de aandeelhouders vanuit het perspectief van de maatschappelijke functie van banken;

- versterking van het toezicht in Nederland op banken;

- de structuur van het Nederlandse bankwezen in de komende jaren.

De aanbevelingen in het rapport van de Commissie Maas hebben nadrukkelijk niet het karakter van zelfregulering en zijn naar het oordeel van de commissie dwingend van aard. De Commissie Maas dringt aan op snelle invoering van haar aanbevelingen. Banken moeten de aanbevelingen uitvoeren, zo niet dan moeten zij uitleggen waarom niet volgens het 'pas toe of leg uit'-beginsel. Het uiteindelijke doel van het rapport van de Commissie Maas is de klanten van banken en daarmee de samenleving als geheel weer optimaal te bedienen en zo het geschonden vertrouwen te herwinnen.

De anbevelingen met betrekking tot de eerste twee genoemde onderwerpen zijn omgezet in de Code Banken.

\subsubsection{Reacties op het Rapport Commissie Maas}

In een eerste reactie meldt de Nederlandse Vereniging van Banken (hierna NVB) dat zij de anbevelingen verwelkomt en dat zij zich actief in zal spannen om spoedig invulling te geven aan de afzonderlijke aanbevelingen. Boele Staal, voorzitter van NVB, reageert later met de opmerking dat voor hem het nut en de noodzaak van de Commissie Maas als een paal boven water staat. 'Terugkijkend op de crisis is mijn analyse dat de Westerse wereld de uiterste kredietgrenzen heeft opgezocht en vaak ook heeft overschreden. Er zijn met name in de VS onverantwoorde risico's genomen, die elders op de balans kwamen. De financiële sector heeft dat niet voorzien' (Staal, 2011).

Toenmalig Minister Bos van Financiën noemt in een brief aan de Tweede Kamer het rapport een welkom rapport en onderschrijft veel van de 'best practices' (Bos 2009). ${ }^{1}$ Bos stelt dat het belangrijk is dat de 'best practices' niet te vrijblijvend zijn en geeft aan na te gaan, hoe de naleving van de 'best practices' bevorderd kan worden. Hij sluit daarbij wettelijke verankering, al dan niet gecombineerd met monitoring, niet uit.

Ook De Nederlandsche Bank (hierna DNB) en de Autoriteit Financiële Markten (hierna AFM) zijn positief over de aanbevelingen van de Commissie Maas. DNB ziet de implementatie van de aanbevelingen als een essentiële stap om het vertrouwen in de bancaire sector te verbeteren. De aanbevelingen met betrekking tot deskundigheid van bestuurders en commissarissen sluiten volgens DNB goed aan bij het door de toezichthouder ontwikkelde normenkader voor deskundigheidstoetsing. DNB hecht aan de 
periodieke inspanning om de deskundigheid op peil te houden en geeft aan dat dit nog meer dan voorheen een belangrijk onderdeel zal worden van het lopende toezicht op banken.

De AFM onderschrijft op hoofdlijnen de aanbevelingen van de Commissie Maas met betrekking tot governance en risicomanagement maar is van mening dat de verhoudingen tussen aandeelhouders, raad van commissarissen (hierna $\mathrm{RvC}$ ) en onderneming meer analyse verdienen, waarbij gewaarborgd moet worden dat de aanbevelingen in lijn zijn met de Nederlandse Corporate Governance Code (hierna Code Tabaksblat).

In een schriftelijke reactie van het Koninklijk Nederlands Instituut van Registeraccountants (NIVRA) wordt onder andere aandacht gevraagd voor de rol en positie van de interne auditor, aangezien die als geen ander in staat is om zich een goed totaalbeeld te vormen van de (operationele) risico's die zich binnen een bank voordoen (NIVRA, 2009). Maas heeft in een door het NIVRA georganiseerde debatbijeenkomst in juni 2009 toegegeven dat de rol van de interne auditor onderbelicht is en zeker meer aandacht verdient in het rapport.

\subsection{Code Banken \\ 2.2.1 Algemeen}

De Code Banken is een initiatief van de NVB en is van oorsprong een voorbeeld van zelfregulering. De Code Banken is op 9 september 2009 gepubliceerd in reactie op de aanbevelingen uit hoofdstuk 1 en 2 van het rapport van de Commissie Maas, en omvat principes op het gebied van naleving Code Banken, de Raad van Commissarissen ( $\mathrm{RvC}$ ), de Raad van Bestuur (hierna RvB), risicomanagement, interne audit en beloningsbeleid. ${ }^{2}$ De Code Banken is hierna verankerd in de wetgeving hetgeen wij zullen beschrijven in paragraaf 2.3.

Volgens de preambule liggen de principes van de Code Banken in het verlengde van de Code Tabaksblat. De Code Tabaksblat geldt onverkort voor beursgenoteerde banken. De preambule stelt bovendien dat niet-beursgenoteerde banken de Code Tabaksblat veelal vrijwillig naleven. ${ }^{3}$ Uit de preambule blijkt niet waarop de veronderstelling van vrijwillige naleving is gebaseerd. Tevens wordt geen nadere toelichting gegeven wat precies wordt bedoeld met de stelling dat de Code Banken in het verlengde ligt van de Code Tabaksblat.

De preambule stelt verder dat de Code Banken niet op zichzelf staat, maar deel uitmaakt van het volledige stelsel van nationale, Europese en internationale wet- en regelgeving, jurisprudentie dat in zijn geheel bezien dient te worden. ${ }^{4}$
Kortom, het is een van de bouwstenen binnen de totale regelgeving.

Een belangrijk vereiste opgenomen in de preambule die betrekking heeft op de externe verantwoording is dat iedere bank elk jaar in haar jaarverslag vermeldt op welke wijze zij de principes van de Code Banken in het voorgaande jaar heeft nageleefd en zet, indien van toepassing, volgens het 'pas toe of leg uit'-beginsel gemotiveerd uiteen waarom een principe eventueel niet (volledig) is toegepast. Iedere bank plaatst dit verslag op haar website.

Onduidelijk is hoe ver deze verantwoording dient te gaan. Is het voldoende als een bank mededeelt dat zij voldoet, of moet per principe aangeven worden op welke wijze deze is toegepast? Het feit dat gesproken wordt over een 'verslag' doet vermoeden dat meer wordt verwacht dan enkel de mededeling dat een bank voldoet. Echter uit het feit dat de Code Banken alleen in principe 3.1.5 expliciet stelt dat een bank in haar jaarverslag verantwoording aflegt over principe 3.1.3, aangaande de aanwezigheid van een programma van permanente educatie, en principe 3.1.4 aangaande de deelname van de RvB aan permanente educatie, zou men kunnen afleiden dat over de toepassing van de andere principes geen uitleg gegeven hoeft te worden in het jaarverslag behoudens de mededeling omtrent naleving.

De Code Banken treedt in werking op 1 januari 2010. Ten tijde van de presentatie van het jaarverslag 2009 doet een bank op haar website verslag van de voorbereidende stappen die in 2009 zijn getroffen om de Code Banken vanaf 1 januari 2010 toe te passen. Vanaf boekjaar 2010 rapporteren de banken jaarlijks over de naleving van de Code Banken. Verder is afgesproken dat de naleving van de Code Banken jaarlijks zal worden onderzocht door een onafhankelijke monitoringscommissie.

De eerste reacties lopen uiteen. Maas zegt in een interview met De Volkskrant (december 2009) in dit kader het volgende: 'In de Code Banken zie je wel het resultaat van polderen dat mijn commissie juist niet heeft gedaan. De Code Banken volgt ons voor 95\% maar bevat verwaterde teksten, herkenbaar aan langere zinnen.' Het Ministerie van Financiën (2009) is echter positiever en meldt dat de Code Banken een unieke stap in de wereld is. Het is voor het eerst dat een bancaire sector met een dergelijk initiatief komt, en kan worden beschouwd als een belangrijke en goede stap op weg naar het herstel van vertrouwen in de financiële sector.

In ons onderzoek beantwoorden wij de vraag hoe de banken de principes van de Code Banken in de praktijk hebben vormgegeven. Hierbij zijn wij uitgegaan van de 
informatie die de banken verstrekken in hun jaarverslagen en/of website. Bepalend bij de invulling van de principes is op welke wijze met de intenties van de Code Banken wordt omgegaan. Volgens de Code Banken dient afvinkgedrag te worden vermeden. Wij gaan nader in op een aantal principes van de Code Banken, die wij relevant vinden, mede gezien het feit dat deze principes relatief nieuw zijn en uit dien hoofde mogelijk extra aandacht zullen krijgen in de jaarverslagen over 2010 van de banken. Daarnaast bespreken wij een aantal principes dat specifiek is ingericht voor banken in aanvulling op de Code Tabaksblat. Hierbij houden wij de volgorde van de Code Banken aan. Wij maken, indien relevant, een vergelijking met de Code Tabaksblat en met de anbevelingen van de Commissie Maas. Wij doen dat alleen voor die principes die wij in het empirisch gedeelte onderzoeken. Voor een volledig overzicht van de wijze waarop de aanbevelingen van Maas in de Code Banken zijn verwerkt, verwijzen wij naar de in de Code Banken opgenomen toelichting.

\subsubsection{Naleving Code Banken}

Het eerste hoofdstuk behandelt het 'pas toe of leg uit'-beginsel. De banken waarop de Code Banken van toepassing is, kennen verschillende corporate governancestructuren, opereren in verschillende (deel)markten en kunnen nationaal of internationaal georiënteerd zijn. Afwijkingen, mits gemotiveerd, kunnen derhalve gerechtvaardigd zijn. Dit principe komt in meerdere governance codes voor en houdt rekening met het feit dat banken op veel gebieden kunnen verschillen.

Alhoewel in de Code Tabaksblat naar aanleiding van onderzoek een vergelijkbare best practice toegevoegd is, inhoudende dat afwijkingen voorzien dienen te zijn van een 'deugdelijke' motivering, verkiest de NVB in de Code Banken, zowel in de preambule als in principe 1, voor een minder strenge formulering.

Ons onderzoek geeft een eerste inventarisatie van de wijze van presenteren van de mededelingen omtrent het 'pas toe of leg uit'-beginsel. Wij hebben daarnaast onderzocht op welke principes de afwijkingen betrekking hebben en in hoeverre gerapporteerde afwijkingen zijn voorzien van een motivering. Aangezien de Code Banken slechts spreekt van een motivering en hieraan geen inhoudelijke eisen stelt, zullen wij hierover geen waardeoordeel geven.

\subsubsection{Raad van Commissarissen}

De Code Banken besteedt in navolging van de Code Tabaksblat (acht principes met 50 best practice bepalingen) relatief veel aandacht (twaalf principes) aan de RvC. De principes hebben betrekking op de samenstelling en deskundigheid en de taak en werkwijze.
In de principes is geen kwantitatieve bepaling opgenomen over de omvang van de raad, zoals de Commissie Maas voorstelde, omdat die omvang niet bepalend behoeft te zijn voor zijn functioneren. ${ }^{5}$

Aanbeveling 1.3 van de Commissie Maas stelt dat de RvC bij een grote bank uit tenminste tien leden en bij een kleine bank uit tenminste zes leden moet bestaan.

Principe 2.1.6 in de Code Banken stelt dat iedere commissaris, de voorzitter in het bijzonder, voldoende beschikbaar en bereikbaar moet zijn om zijn taak naar behoren te vervullen. De Code Banken stelt echter, in tegenstelling tot de Code Tabaksblat, geen eisen aan het maximum aantal nevenfuncties dat kan worden gecombineerd met het lidmaatschap van de $\mathrm{RvC}$.

Een aantal principes gaat inhoudelijk in op de deskundigheid van commissarissen (principes 2.1.3-2.1.5). De aanbeveling van de Commissie Maas dat de voorzitter van de RvC ruime ervaring in de financiële sector moet hebben, is uitgewerkt in het principe dat in de profielschets van de voorzitter aandacht wordt besteed aan de door de bank gewenste deskundigheid en ervaring met de financiële sector (principe 2.1.4).

Een aanvullend principe met betrekking tot deskundigheid is de verplichting om een programma van permanente educatie voor commissarissen in te stellen (principe 2.1.8). De Code Tabaksblat beschrijft alleen een introductieprogramma voor nieuwe leden. Het principe noemt een antal onderwerpen dat behandeld dient te worden in het programma van permanente educatie. Verder bepaalt de Code Banken dat ieder lid van de RvC deelneemt aan het programma. De door Maas voorgestelde maatregel om bij het niet voldoen aan deze verplichting DNB op te laten treden is niet overgenomen in de Code Banken. De beoordeling van de effectiviteit van het programma maakt volgens de Code Banken deel uit van de jaarlijkse zelfevaluatie van de $\mathrm{RvC}$ (principe 2.1.9).

In aanvulling op best practice bepaling III.1.7 van de Code Tabaksblat die een jaarlijkse zelfevaluatie voorschrijft, stelt de Code Banken in principe 2.1.o dat deze zelfevaluatie eens in de drie jaar geschiedt onder onafhankelijke begeleiding. Hierbij maken de volgende aspecten deel uit van deze evaluatie: de betrokkenheid van iedere commissaris en de cultuur binnen de $\mathrm{RvC}$ en de RvB. De Code Tabaksblat vereist dat in het verslag van de $\mathrm{RvC}$ wordt vermeld op welke wijze de jaarlijkse zelfevaluatie heeft plaatsgevonden. De Code Banken vereist niet dat banken in het $\mathrm{RvC}$-verslag of directieverslag nadere informatie opnemen over de evaluatie onder onafhankelijke begeleiding. 
Een laatste relevant principe (principe 2.2.2) met betrekking tot de $\mathrm{RvC}$ is het instellen van een risicocommissie. Voor de leden van deze commissie gelden specifieke competentie- en ervaringseisen. De taken van de risicocommissie kunnen ook worden neergelegd bij een andere specifieke commissie, in veel gevallen de auditcommissie. Het risicobeheer is namelijk onderdeel van de scope van de auditcommissie (Jansman en Van Manen, 2010). Met name bij kleinere banken kan niet altijd in een separate risicocommissie worden voorzien, aldus de toelichting op de Code Banken. Hiermee wijkt de Code Banken af van de aanbevelingen van de Commissie Maas, die heeft geadviseerd dat een bank altijd over een afzonderlijke risicocommissie en auditcommissie dient te beschikken.

Wij hebben onderzocht of de banken in de jaarrapporten aandacht besteden aan de zelfevaluaties onder onafhankelijke begeleiding en aan het programma van permanente educatie. Wij hebben tevens onderzocht of banken een risicocommissie hebben ingesteld.

\subsubsection{Raad van Bestuur}

Hoofdstuk 3 van de Code Banken kent twaalf principes die zich richten op de $\mathrm{RvB}$, tegenover vier principes en 30 best practice bepalingen in de Code Tabaksblat. Net zoals in het hoofdstuk over commissarissen hebben de principes betrekking op samenstelling en deskundigheid alsmede op taak en werkwijze. Net zoals bij de principes over de $\mathrm{RvC}$ introduceert principe 3.1.3 een programma van permanente educatie, waarin minimaal dezelfde onderwerpen aandacht dienen te krijgen als die genoemd bij de RvC. Ook hier geldt dat alle leden van de RvB deel moeten nemen aan het programma. Het is uit pragmatisch oogpunt te verwachten dat de twee programma's worden gecombineerd.

De $R v C$ vergewist zich ervan of de leden van de RvB kunnen blijven voldoen aan de deskundigheidseisen van DNB (principe 3.1.4). De toelichting op de Code Banken stelt hier het volgende over: 'Het door de Commissie Maas geformuleerde bankexamen voor nieuwe bestuurders wordt door de Code Banken zo ingevuld dat niet alleen nieuwe maar ook zittende, kortom alle leden van de raad van bestuur over permanente grondige kennis dienen te beschikken.' Het programma kan bovendien het horizontaal instromen van personen van buiten de financiële sector in de RvB faciliteren.

Zoals eerder opgemerkt is het opvallend dat principe 3.1.5 expliciet voorschrijft dat banken in hun jaarverslag moeten vermelden op welke wijze invulling is gegeven aan de principes inzake permanente educatie. Dit is namelijk het enige principe waarin expliciet wordt voorgeschreven dat verantwoording afgelegd moet worden in het jaarverslag over hoe invulling gegeven is aan principes 3.1.3 en 3.1.4, naast de algemene mededeling omtrent naleving. Wij hebben dit aspect tevens in ons onderzoek betrokken.

Principe 3.2.3 stelt dat de leden van de RvB hun functie uitoefenen op een zorgvuldige, deskundige en integere manier met inachtneming van de van toepassing zijnde wet- en regelgeving, codes en reglementen. Ieder lid van de RvB tekent een moreel-ethische verklaring waarvoor in de toelichting op de Code Banken een model is opgenomen. Dit model kan iedere bank naar eigen inzicht aanvullen in lijn met het specifieke karakter en profiel van de bank. De in de verklaring beschreven principes worden vertaald in principes die gelden als leidraad voor het handelen van alle medewerkers van de bank. Niet alleen de integriteit van de leiding is belangrijk, een integere bedrijfsvoering van een bank kan alleen tot stand komen indien de integriteit is geïncorporeerd in de processen van de bank (Annink et al., 2006).

Opvallend is dat de toelichting op de Code Banken stelt dat de banken deze verklaring openbaar maken op de website van de desbetreffende bank en niet in het jaarverslag.

Wij hebben onderzocht in hoeverre in de jaarverslagen is toegelicht hoe invulling is gegeven aan de principes omtrent permanente educatie en aan het principe ten aanzien van de moreel-ethische verklaring.

\subsubsection{Risicomanagement}

Risicomanagement is primair de verantwoordelijkheid van de RvB maar wordt, gezien het belang van dit onderwerp binnen de bancaire sector, in een afzonderlijk hoofdstuk van de Code Banken behandeld. Dit hoofdstuk bevat vijf principes. De toezichthoudende taak van de $\mathrm{RvC}$ op het gevoerde risicobeleid wordt in dit hoofdstuk eveneens verder uitgewerkt.

Aan de basis van het risicobeleid van de bank ligt de risicobereidheid. Dit essentiële onderdeel van risicomanagement is nieuw en wordt in de Code Tabaksblat niet genoemd. De Code Banken omschrijft dit begrip in de preambule als 'de mate van redelijkerwijs voorzienbaar risico die de bank gezien haar voorgenomen activiteiten bereid is te accepteren bij het nastreven van haar doelstellingen.'

In principe 4.5 gaat de Code Banken gedetailleerd in op het Product Goedkeuringsproces. Producten worden niet eerder op de markt gebracht dan na het doorlopen van dit proces, waarbij een zorgvuldige afweging door de risicomanagementfunctie plaatsvindt van de risico's en een zorgvuldige toetsing van andere aspecten, waaronder de 
zorgplicht ten opzichte van de klant. De Commissie Maas (2009) formuleert het nog strenger (aanbeveling 1.29): 'Nieuwe producten kunnen niet op de markt worden gebracht of worden gedistribueerd zonder uitdrukkelijke instemming van de riskmanagementfunctie in de bank.'

De preambule van de Code Banken licht hierover nog het volgende toe: 'Met dit proces wordt de procedure bedoeld volgens welke de bank beslist of een bepaald product voor eigen rekening en risico of ten behoeve van haar klanten zal worden geproduceerd of gedistribueerd. Bij dit proces wordt breed getoetst op aspecten van zorgplicht en het beheersen van risico's. De interne auditfunctie controleert op basis van een jaarlijkse risicoanalyse of opzet, bestaan en werking van dit proces effectief zijn en informeert de RvB en de risicocommissie van de $\mathrm{RvC}$ omtrent de uitkomsten hiervan.' Het valt op dat de door Maas voorgestelde stevige verankering van de Chief Risk Officer in de RvB niet is overgenomen in de Code Banken.

Staal (voorzitter NVB) zegt in dit kader dat het goedkeuren van bancaire producten van wezenlijk belang is. 'Die mogen niet meer aanbod gedreven zijn, maar moeten een aantoonbaar antwoord geven op consumentenvragen uit de markt. En er moet een zorgvuldige afweging van alle mogelijke risico's hebben plaatsgevonden' (Staal, 2011). Wij onderzoeken de informatie over het Product Goedkeuringsproces en de controle hierop door de interne auditfunctie.

\subsubsection{Audit}

Een relevante component van de governancestructuur wordt gevormd door een onafhankelijke interne auditfunctie (Annink et al., 2006). De Code Banken werkt met name de plaats, taken en verantwoordelijkheden van de interne auditfunctie uit teneinde een systematische controle op de beheersing van de risico's van de bank mogelijk te maken. De interne auditfunctie dient derhalve onafhankelijk gepositioneerd te zijn. Dit wordt bereikt via een directe rapportagelijn naar de voorzitter van de RvB en naar de voorzitter van de auditcommissie van de RvC. Periodieke afstemming van informatie tussen de interne auditfunctie, de externe accountant en de auditcommissie is eveneens van belang voor de beheersing van de risico's. De externe accountant rapporteert in het kader van zijn algemene controleopdracht voor de jaarrekening zijn bevindingen over de kwaliteit en effectiviteit van het functioneren van de governance, het risicobeheer en de beheersprocessen binnen de bank aan de RvB en de RvC.

Principe 5.6 tot slot stelt dat de interne auditfunctie het initiatief neemt om in een vroegtijdige fase tenminste jaarlijks een bespreking met DNB en de externe accountant te organiseren waarin elkaars risicoanalyses, bevindingen en auditplannen worden besproken. Dit (tripartiete) overleg bestaat al langer en is specifiek voor de bancaire sector. Over de waarde van dit overleg lopen de meningen uiteen. Korf (2010) acht het tripartiete overleg relevant voor het versterken van de communicatie tussen de interne en externe accountant en DNB. Via dit principe in de Code Banken wordt getracht om het tripartiete overleg nieuw leven in te blazen.

Wij onderzoeken de aanwezigheid van een interne auditfunctie, de positie van deze functie en de toelichting die de banken geven over het tripartiete overleg.

\subsubsection{Beloningsheleid}

Het laatste hoofdstuk in de Code Banken gaat over het beloningsbeleid. Een onderwerp dat in Nederland in de media en van de politici veel aandacht krijgt, mede ingegeven door de perceptie dat de kredietcrisis vooral is veroorzaakt door de prikkels in het beloningsbeleid van banken.

De RvC wordt door de Code Banken een zwaardere taak toebedeeld dan door de Code Tabaksblat. De RvC houdt niet alleen toezicht op de beloningen van het bestuur maar keurt ook het beloningsbeleid van het senior management en de beginselen van het beloningsbeleid voor de overige medewerkers goed.

De RvC bespreekt jaarlijks de hoogste variabele inkomens alsmede specifieke beloningspakketten en ziet er op toe dat deze passen binnen het beloningsbeleid en niet excessief zijn. Variabele beloningen toegekend aan de leden van de RvB zijn mede gerelateerd aan langetermijndoelstellingen van de bank en worden voor een materieel deel voorwaardelijk toegekend en op zijn vroegst drie jaar later uitgekeerd. Deze beloningen bedragen per jaar niet meer dan $100 \%$ van het vaste inkomen en kunnen worden teruggevorderd als achteraf blijkt dat ze zijn toegekend op basis van onjuiste (financiële) gegevens. De RvC heeft de discretionaire bevoegdheid om de variabele beloning aan te passen wanneer deze naar zijn oordeel leidt tot onrechtvaardige of onbedoelde uitkomsten.

Voor de overige medewerkers van de bank worden in principe 6.4.3 eveneens eisen gesteld aan de variabele beloningen. Zo dienen naast financiële prestatiecriteria ook niet-financiële criteria gehanteerd te worden. Dit onderdeel van de Code Banken heeft in het bijzonder betrekking op medewerkers met functies die het risicoprofiel van de bank beïnvloeden, aldus de toelichting. De Code Banken gaat hierin verder dan de Code Tabaksblat, die maar zeer beperkt aandacht besteedt aan de variabele beloningen van de medewerkers. 
Gezien de aandacht dat het onderwerp beloningsbeleid gekregen heeft in andere onderzoeken en doordat toetsing van naleving veelal meer informatie vereist dan publiekelijk beschikbaar is, hebben wij besloten geen verder onderzoek te doen naar het beloningsbeleid. Wel brengen wij in kaart in hoeverre banken afwijkingen hebben gerapporteerd met betrekking tot de principes die het beloningsbeleid behandelen.

\subsection{Besluit}

De wettelijke verankering van de Code Banken wordt geregeld in het Besluit van 1 juni 2010 tot vaststelling van nadere voorschriften omtrent de inhoud van het jaarverslag van banken (hierna 'Besluit'). Het definitieve Besluit is 11 juni 2010 ondertekend door de Minister van Justitie. In artikel 2 van dit Besluit wordt de Code Banken zoals gepubliceerd in de Staatscourant van 23 december 2009 aangewezen als code bedoeld in artikel 391 lid 5 boek 2 BW. De Code Banken is van toepassing op jaarverslagen die betrekking hebben op een boekjaar dat aanvangt op of na 1 januari 2010.

In artikel 3 lid 5 van het Besluit is bepaald dat de banken in hun jaarverslag in een specifiek onderdeel betreffende corporate governance, mededeling doen over de naleving van de principes van de Code Banken volgens het'pas toe of leg uit'-beginsel. Zij hebben ook de mogelijkheid om deze informatie te verstrekken in een bijlage of langs elektronische weg'. Indien een bank gebruik maakt van de mogelijkheid om de mededeling te doen als bijlage bij het jaarverslag vindt een afzonderlijke deponering plaats. Wij hebben geen onderzoek verricht naar het deponeren van mededelingen als bijlage aangezien uitgangspunt van het onderzoek het jaarrapport en de website is geweest.

Indien een bank gebruik maakt van de mogelijkheid om een mededeling te doen langs elektronische weg, dient het jaarverslag een verwijzing te bevatten naar de website. De mededeling dient daar rechtstreeks en permanent toegankelijk te zijn. Deze mededeling wordt door deze verwijzing geacht onderdeel uit te maken van het jaarverslag.

In geval de bank aan het hoofd staat van een groep, kan die bank in het jaarverslag mededeling doen over de naleving van de Code Banken ten aanzien van de groep als geheel (artikel 3 lid 2). De desbetreffende dochtermaatschappijen behoeven dan niet afzonderlijk informatie te verschaffen over de naleving van de Code Banken, mits zij in hun jaarverslag verwijzen naar de mededeling van de groep als geheel (artikel 3 lid 3$)$.

\subsection{Monitoring Commissie Code Banken}

Op 24 maart 2010 bericht Minister De Jager van Financiën aan de Tweede Kamer dat een onafhankelijke Monitoring Commissie in het leven is geroepen met als voorzitter de heer Burgmans, oud CEO van Unilever. De commissie heeft de opdracht aanvaard onder de voorwaarde dat het Ministerie van Financiën gedurende drie jaar geen wetgeving initieert die het gebied van de Code Banken bestrijkt.

De hoofdtaak van de commissie is het toezicht houden op de naleving van de principes Code Banken, volgens het 'pas toe of leg uit'-beginsel. Indien de commissie onduidelijkheden en onevenwichtigheden in de Code Banken signaleert, kan zij aanbevelingen doen over mogelijke aanpassingen in de principes. De commissie rapporteert aan de Minister van Financiën en aan de NVB. De minister en de NVB kunnen de commissie verzoeken bepaalde aspecten uit de Code Banken te onderzoeken. De NVB zal in overleg met de minister van Financiën de Code Banken vóór 1 januari 2013 evalueren.

In december 2010 heeft de Monitoring Commissie Code Banken een voorrapportage uitgebracht waarin een beeld wordt gegeven van de stand van zaken met betrekking tot de implementatie van de Code Banken op basis van een onderzoek uitgevoerd onder 43 banken op basis van websites en andere publieke informatie, enquêtes en interviews. De commissie constateert dat de eerste resultaten van de toepassing van de Code Banken bemoedigend zijn, maar dat de urgentie en prioriteit in de loop van 2011 nog verhoogd zullen moeten worden om het vertrouwen van de samenleving daadwerkelijk terug te winnen.

De commissie voorziet dat de bancaire sector nog een 'zware dobber' zal hebben om de Code Banken verder te implementeren. 'Openheid van geest en transparantie van handelen zijn sleutelfactoren voor succes. Een transparante houding, waarbij de samenleving de voortgang kan volgen, zal daarbij in hoge mate kunnen bijdragen tot het herwinnen van het verloren vertrouwen.'

In de inleiding van dit rapport schrijft de commissie wel dat de banken een redelijke termijn gegund moet worden om het veeleisende pakket van de Code Banken te implementeren. Ons artikel zal mogelijk het implementatietraject ondersteunen door het doen van aanbevelingen en het identificeren van best practices.

\section{Empirisch Onderzoek \\ 3.1 Opzet onderzoek}

De onderzoekspopulatie bestaat uit alle banken die beschikken over een bankvergunning volgens de Wet op het financieel toezicht (Wft) met zetel in Nederland voor het gehele boekjaar 2010. Wij hebben alleen die banken betrokken in ons onderzoek waarvan de jaarrapporten op 1 juli 2011 beschikbaar waren op de website van de desbetreffende onderneming of op de website van de Kamer van Koophandel, aangezien de wettelijke deponeringstermijn 30 juni 2011 is. Een aantal Nederlandse banken, die gecon- 
solideerd worden in een groep, maakt gebruik van de vrijstelling die geregeld is in artikel 403 boek $2 \mathrm{BW}$ en brengt derhalve niet zelfstandig een jaarrapport uit. Wij hebben in het geval van de gebruikmaking van een vrijstelling het jaarrapport van de moedermaatschappij in ons onderzoek betrokken. Onze interpretatie is dat in deze situatie de moeder verslag dient te doen over de naleving van de Code Banken voor de dochter met de desbetreffende bankvergunning. Indien de moedermaatschappij van een bank die gebruik maakt van de vrijstelling al zelfstandig in het onderzoek is opgenomen, is de dochterbank buiten de populatie gelaten. Onze definitieve onderzoekspopulatie bestaat uit 38 banken. Wij verwijzen voor de gedetailleerde lijst naar bijlage 1 .

De Code Banken schrijft niet voor waar de informatie betreffende de naleving van de Code Banken opgenomen dient te worden in het jaarrapport. Wij onderzoeken om deze reden het gehele niet-financiële gedeelte van het rapport. Hieronder valt het directieverslag, zijnde jaarverslag in de zin van artikel 391 boek $2 \mathrm{BW}$, inclusief risicoparagraaf en corporate governance-hoofdstuk en informatie die formeel niet deel uitmaakt van het directieverslag, zoals verslag van de $\mathrm{RvC}$ en overige informatie, waaronder aandeelhoudersinformatie. Buiten de reikwijdte van ons onderzoek vallen de jaarrekening en overige gegevens (artikel 2:361 BW).

Indien het jaarverslag voor informatie betreffende de naleving van de Code Banken een verwijzing omvat naar de website in overeenstemming met artikel 3 lid 5 van het Besluit, hebben wij deze informatie zo veel mogelijk betrokken in ons onderzoek. Hierbij hebben wij geen onderscheid gemaakt in informatie op de internetpagina's van de onderneming en informatie met behulp van een separaat document. ${ }^{6}$

Wij gaan in ons onderzoek eerst in op andere governancecodes en concentreren ons hierna op de onderwerpen van de Code Banken die zijn geïdentificeerd in paragraaf 2. Wij hanteren hierbij de volgorde van de onderwerpen in de Code Banken.

Wij hebben gebruik gemaakt van de volgende subcategorieën indien dit relevante informatie oplevert:

- beursgenoteerde banken in Nederland;

- dochtermaatschappijen van in het buitenland beursgenoteerde banken;

- niet-beursgenoteerde banken;

- dochtermaatschappijen die gebruikmaken van de vrijstelling in artikel 403 boek 2 BW waarvan de jaarrapporten van de moedermaatschappij meegenomen zijn in het onderzoek.

\subsection{Governancecodes}

Zoals beschreven in paragraaf 2.2.1 kunnen banken ook met andere governancecodes te maken hebben. Nederlandse beursgenoteerde banken dienen bijvoorbeeld ook de Code Tabaksblat na te leven. Ook deze code is net als de Code Banken wettelijk verankerd. Zoals vermeld, stelt de NVB dat de principes in de Code Banken in het verlengde liggen van de Code Tabaksblat. Op basis hiervan kan volgens de NVB ervan uitgegaan worden dat niet-beursgenoteerde banken de Code Tabaksblat veelal vrijwillig naleven.

Uit ons onderzoek blijkt dat zeven (19\%) banken als gevolg van een beursnotering in Nederland dienen te voldoen aan de Code Tabaksblat.? Deze banken hebben derhalve al een aantal jaren ervaring met het naleven van een governance code. Hiernaast vermelden veertien ( $37 \%$ ) banken dat zij de Code Tabaksblat vrijwillig naleven. Hierbij merken wij op dat de Monitoring Commissie Corporate Governance Code, in tegenstelling tot de beursgenoteerde banken, de banken met vrijwillige naleving niet jaarlijks onderzoekt.

Sommige (moeders) van (Nederlandse) banken hebben ook een beursnotering in het buitenland, waar eveneens corporate governance codes zijn ingevoerd. Een bekend voorbeeld is de strenge Sarbanes-Oxley Act in de Verenigde Staten. In de onderzoekspopulatie bevinden zich dertien (34\%) banken die onder een buitenlandse moedermaatschappij vallen, waarvan acht (21\%) moedermaatschappijen beursgenoteerd zijn. Dat betekent dat zij waarschijnlijk eveneens nationale governancecodes na dienen te leven. In enkele gevallen hebben wij in de door ons onderzochte jaarverslagen een verwijzing aangetroffen naar die buitenlandse codes. Wij noemen in dit verband als voorbeelden: banken in Frankrijk, het Verenigd Koninkrijk, Duitsland, Zwitserland en Turkije.

\subsection{Naleving Code Banken}

Uit hoofde van principe 1 dienen banken een uitspraak te doen in hoeverre zij voldoen aan de principes van de Code Banken volgens het 'pas toe of leg uit'-beginsel. Tabel 1 laat zien waar informatie over de Code Banken openbaar, dus zowel in het jaarverslag als op de website, beschikbaar is. Tevens hebben wij onderzocht of sprake is van een verwijzing in het jaarverslag naar de website in het geval dat aanvullende informatie op de website is geplaatst. Achterliggende reden is dat volgens het Besluit alleen in het geval van een verwijzing, de website formeel deel uitmaakt van het jaarverslag.

35 (92\%) van de 38 onderzochte banken doen een mededeling over de naleving van de Code Banken. De meerderheid, namelijk twintig (53\%) banken, heeft informatie 
Tabel 1 plaats waar informatie is opgenomen over de Code Banken

\begin{tabular}{|c|c|c|c|c|c|}
\hline Informatie opgenomen in: & Beurs-genoteerd & $\begin{array}{l}\text { Beursgenoteerd } \\
\text { buitenland }\end{array}$ & $\begin{array}{c}\text { Niet } \\
\text { beursgenoteerd }\end{array}$ & $\begin{array}{l}\text { Vrijstelling verslag } \\
\text { door moeder }\end{array}$ & Totaal \\
\hline $\begin{array}{l}\text { Zowel jaarverslag als website; jaarverslag } \\
\text { omvat een verwijzing naar website }\end{array}$ & 4 & 2 & 7 & 1 & $14(37 \%)$ \\
\hline $\begin{array}{l}\text { Zowel jaarverslag als website; jaarverslag } \\
\text { omvat geen verwijzing naar website }\end{array}$ & 0 & 1 & 5 & 0 & $6(16 \%)$ \\
\hline Alleen in jaarverslag, niet op de website & 2 & 5 & 7 & 1 & $15(39 \%)$ \\
\hline $\begin{array}{l}\text { Geen informatie opgenomen in zowel } \\
\text { jaarverslag als website }\end{array}$ & 0 & 0 & 1 & 2 & $3 \quad(8 \%)$ \\
\hline Totaal & 6 & 8 & 20 & 4 & $38(100 \%)$ \\
\hline
\end{tabular}

opgenomen zowel in het jaarverslag als op de website. Veertien (37\%) banken hiervan hebben ook een verwijzing naar de website opgenomen in het jaarverslag.

Opvallend is dat zes (16\%) banken wel informatie verstrekken via de website maar geen verwijzing hiernaar opnemen in het jaarverslag. Op deze wijze valt de informatie volgens het Besluit dus buiten het directieverslag. Voor de vaststelling of deze banken al dan niet voldoen aan de principes van de Code Banken hebben wij de website derhalve eveneens buiten beschouwing gelaten. Hierdoor kan het zo zijn dat de materiële toepassing van de Code beter is dan in het navolgende gepresenteerd.

Vijftien (39\%) banken hanteren als verantwoordingsmiddel alleen het jaarverslag. Uit tabel 2 blijkt dat dit voor een groot deel de aan een buitenlandse beurs genoteerde banken betreft en ruim een derde van de niet-beursgenoteerde banken. Zij voldoen dus niet aan het vereiste in de preambule van de Code Banken waarin wordt gesteld dat de bank het verslag ook op de website plaatst.

Drie (8\%) banken doen helemaal geen verslag over de toepassing van de principes. In één geval betreft dit een niet-beursgenoteerde bank in Nederland en tweemaal een buitenlandse moedermaatschappij van een Nederlandse vestiging die gebruik maakt van de 403-vrijstelling. Wij hebben geen navraag gedaan naar de achterliggende reden achter het niet-openbaar maken van nadere informatie over de naleving van de Code Banken.

Tabel 2 omvat de wijze van het presenteren van de mededeling omtrent het 'pas toe of leg uit'-beginsel. Zoals uit de tabel blijkt loopt de wijze van rapporteren in het jaarverslag, zoals vereist in de preambule van de Code Banken, uiteen.

Drie (8\%) banken vermelden expliciet dat zij de principes van de Code Banken volledig toepassen. Deze drie banken hebben tevens per principe inzicht gegeven hoe zij deze toepassen. Eén bank heeft dit integrale verslag opgenomen in het jaarverslag, twee banken hebben in het jaarverslag verwezen naar een document op de website waarin per principe informatie is verstrekt.

Achttien (47\%) banken doen een mededeling waarin expliciet gemeld wordt van welke principes zij afwijken. Onder expliciet verstaan wij dat helder is aangegeven van welke

\section{Tabel 2 Mededeling omtrent naleving principes}

\begin{tabular}{|l|c|c|c|c|c|}
\hline Expliciete mededeling & Beurs-genoteerd & $\begin{array}{c}\text { Beursgenoteerd } \\
\text { buitenland }\end{array}$ & $\begin{array}{c}\text { Niet } \\
\text { beursgenoteerd }\end{array}$ & $\begin{array}{c}\text { Vrijstelling verslag } \\
\text { door moeder }\end{array}$ & Totaal \\
\hline $\begin{array}{l}\text { Volledig compliant en bespreking van alle } \\
\text { principes }\end{array}$ & 2 & 0 & 1 & 0 & $3(8 \%)$ \\
\hline $\begin{array}{l}\text { Comply or explain: bespreking alle } \\
\text { principes }\end{array}$ & 0 & 1 & 9 & 0 & $10(26 \%)$ \\
\hline $\begin{array}{l}\text { Comply or explain en hierbij alleen } \\
\text { afwijkingen toegelicht }\end{array}$ & 3 & 2 & 3 & 0 & $8(21 \%)$ \\
\hline Impliciete mededeling & 1 & 5 & 6 & 2 & $14(37 \%)$ \\
\hline Niet toegelicht & 0 & 0 & 1 & 2 & $3(8 \%)$ \\
\hline Totaal & 6 & 8 & 20 & 4 & $38100 \%$ \\
\hline
\end{tabular}


Figuur 1 Best practice omtrent mededeling naleving: Credit Europe Bank, website.

\begin{tabular}{|c|c|c|c|}
\hline & Principle & $\begin{array}{l}\text { Is Gredit Europe Bank } \\
\text { In BOMPLIANGE or is } \\
\text { EXPLANATION given? }\end{array}$ & BEB Notes \\
\hline 2. & SUPERVISORY BOARD & & \\
\hline 2.1 & COMPOSITION AND EXPERTISE & & \\
\hline 2.1.1 & $\begin{array}{l}\text { The supervisory board shall be composed in } \\
\text { such a way that it is able to perform its tasks } \\
\text { properly. Complementarity, a collegial board, } \\
\text { independence and diversity are preconditions for } \\
\text { the supervisory board to perform its tasks } \\
\text { properly. }\end{array}$ & Partial compliance & $\begin{array}{l}\text { Since February } 2011 \text { Credit Europe Bank ("CEB")'s Supervisory } \\
\text { Board ("SB") consists of seven (7) members; all members having } \\
\text { a lifelong experience in the banking- and legal business. } \\
\text { With the joining of a second independent }{ }^{1} \text { SB-member in February } \\
2011 \text {, CEB realised a further step in increasing the diversity and } \\
\text { level of independence in its supervisory body - however, the } \\
\text { respective Boards of CEB fully acknowledge that the current ratio } \\
\text { of dependent/independent supervisors is still not satisfactory. In } \\
\text { the coming years the SB and Managing Board will consider further } \\
\text { action in this respect. }\end{array}$ \\
\hline 2.1.2 & $\begin{array}{l}\text { The supervisory board shall have a sufficient } \\
\text { number of members to properly perform its } \\
\text { function, including in its committees. The } \\
\text { appropriate number of members depends on the } \\
\text { nature, size and complexity of the bank. }\end{array}$ & Compliance & $\begin{array}{l}\text { The total number of } 7 \text { SB-members is deemed a sufficient number } \\
\text { by the Board(s) taking into account CEB's size, nature and scope } \\
\text { of services and products. }\end{array}$ \\
\hline
\end{tabular}

principes is afgeweken. Dit kan door op dezelfde plaats de afwijkingen op te nemen, of door het bespreken van alle principes, zowel de principes die worden toegepast, als principes waarvan wordt afgeweken inclusief gemotiveerde uitleg. Een voorbeeld hiervan is Credit Europe Bank, die per principe verslag doet en dit als een document op de website heeft geplaatst. De bank geeft bovendien per principe duidelijk aan of sprake is van 'pas toe' of 'leg uit'.

Bij ruim een derde van de banken is sprake van een nietexpliciete mededeling. 'Niet expliciet' wil zeggen dat in de mededeling niet duidelijk is vermeld dat volledig wordt voldaan aan de Code Banken, of van welke principes is afgeweken. Alleen door het integraal lezen van het gehele jaarverslag en eventueel website kan goed inzicht worden verkregen in de naleving van de principes. Voorbeelden hiervan die wij hebben aangetroffen zijn situaties waarin wel vermeld is dat sprake is van afwijkingen, maar niet precies welke, of dat vermeld is dat het 'pas toe of leg uit'-principe is toegepast en dat deze 'hieronder' uitgewerkt is.

Van de 21 (55\%) banken die expliciet melding maken van volledige naleving, of van de afwijkingen, hebben wij onderzocht welke afwijkingen gerapporteerd worden. Wij hebben de niet-expliciete mededelingen niet in dit deelonderzoek meegenomen, aangezien niet zeker is of de afwijkingen volledig zijn gerapporteerd en wij niet in staat zijn om zelfstandig onderzoek te doen naar de naleving van de Code Banken, zoals opgedragen aan de Monitoring Commissie Code Banken. Zoals in tabel 3 vermeld is, rapporteren de banken met een expliciete mededeling in totaal 47 afwijkingen van de Code banken, gemiddeld 2,2 afwijkingen per bank uitgaande van de deelpopulatie van 21. Andersom geredeneerd betekent dit dat de banken die expliciet rapporteren, gemiddeld voldoen aan 45,8 van de 48 principes, hetgeen neerkomt op een compliance van 95,4\%. Mogelijk zou bij het onderzoeken van de naleving door de volledige bankenpopulatie een andere mate van compliance blijken. ${ }^{8}$

Wij hebben ook onderzocht op welke principes de gerapporteerde afwijkingen betrekking hebben. De meeste afwijkingen hebben betrekking op het beloningsbeleid (twintig afwijkingen) en de RvC (twaalf afwijkingen). In

Tabel 3 Overzicht afwijkingen op principes Code Banken

\begin{tabular}{|l|c|}
\hline Onderwerp Gode Banken & Afwijkingen \\
\hline Raad van Commissarissen & 12 \\
\hline Raad van Bestuur & 8 \\
\hline Risk Management & 6 \\
\hline Audit & 1 \\
\hline Beloningsbeleid & 20 \\
\hline Totaal & 47 \\
\hline
\end{tabular}


bijlage 2 is een volledige lijst met afwijkingen opgenomen van de 21 banken met een expliciete mededeling. Relatief weinig afwijkingen zijn gerapporteerd bij de principes betreffende Risk Management en Audit. Hierbij dient te worden opgemerkt dat deze onderwerpen relatief weinig principes kennen.

Op alle 47 gerapporteerde afwijkingen is door de 21 banken een toelichting gegeven. Aangezien zowel principe 1 als de preambule geen eisen stelt aan de kwaliteit van de motivering geven wij in ons onderzoek geen waardeoordeel bij de kwaliteit van de toelichtingen omtrent de afwijkingen.

Veel toelichtingen hebben betrekking op het feit dat de bank in 2010 nog niet voldoet, maar in de toekomst wel zegt te zullen voldoen. Naar verwachting zal het aantal afwijkingen in volgende boekjaren derhalve afnemen ten opzichte van 2010.

Zoals vermeld is het aantal afwijkingen met betrekking tot beloningsbeleid opvallend. De meeste afwijkingen hebben betrekking op de ontslagvergoeding, de hoogte van de variabele beloning en de prestatiecriteria van de variabele beloning. Genoemde toelichtingen betreffen veelal het respecteren van bestaande contracten en het stapsgewijs in lijn brengen met de Code Banken, waaruit blijkt dat de bank wel de intentie heeft om in de (nabije) toekomst te gaan voldoen. Wij hebben echter ook motiveringen aangetroffen waaruit blijkt dat banken bewust afwijken van de principes. Zo geeft een bank aan dat in het huidige beloningsbeleid rekening is gehouden met factoren zoals salarissen bij vergelijkbare bedrijven in de financiële sector, werkdruk en verantwoordelijkheden. Een ander voorbeeld is een bank die stelt wel te voldoen aan een andere (buitenlandse) governancecode die minder stringente eisen stelt.

\subsection{Raad van Commissarissen}

In de Code gaat veel aandacht uit naar de toezichthoudende rol van de RvC. Paragraaf 2.2.3 beschrijft dat volgens de Code de RvC bijzondere aandacht dient te schenken aan het risicobeheer van de bank en om die reden een afzonderlijke risicocommissie dient in te stellen. Uit tabel 4 blijkt dat dertien (34\%) banken een afzonderlijke risicocommissie hebben ingesteld en dat vijftien (39\%) banken de taken van deze commissie hebben neergelegd bij een andere commissie. Dit is in veertien gevallen de auditcommissie. Zeker bij kleinere banken is dat een voor de hand liggende keuze, zoals ook uit de toelichting op de Code Banken valt op te maken.

In hoeverre bij grote banken de instelling van een nieuwe risicocommissie naast een veelal reeds bestaande auditcommissie bij zal dragen aan het versterken van het toezicht op het risicobeheer van de bank, valt nu nog niet te zeggen. Vast staat wel dat de onderlinge afstemming tussen de twee commissies van groot belang is. De toekomst zal uitwijzen of een afzonderlijke risicocommissie bijdraagt aan de effectiviteit van het toezicht.

Tien (26\%) banken hebben geen risicocommissie ingesteld, of hebben hierover geen toelichting verstrekt. Een motivatie die wij meerdere keren hebben aangetroffen is dat risicobeheer dermate belangrijk is, dat de $\mathrm{RvC}$ als geheel hier toezicht op moet houden. Andere RvC's zijn te klein om een afzonderlijke risicocommissie in te stellen.

De Commissie Maas is van mening dat een $\mathrm{RvC}$ van een bank uit minstens zes leden moet bestaan en bij grote banken uit minstens tien leden. Uit ons onderzoek blijkt dat de RvC van de Nederlandse banken gemiddeld uit zeven leden bestaat. Bij zeven (18\%) banken bestaat de RvC uit slechts drie leden, acht (21\%) banken hebben een $\mathrm{RvC}$ van vier tot vijfleden. De vier grootste Nederlandse banken hebben gemiddeld tien commissarissen en voldoen hiermee aan de anbeveling van de Commissie Maas. Sommige banken van buitenlandse ondernemingen hebben zelfs meer dan vijftien commissarissen.

Tabel 4 Risicocommissie

\begin{tabular}{|c|c|c|c|c|c|}
\hline & Beursgenoteerd & $\begin{array}{c}\text { Beursgenoteerd } \\
\text { buitenland }\end{array}$ & $\begin{array}{c}\text { Niet } \\
\text { beursgenoteerd }\end{array}$ & $\begin{array}{l}\text { Vrijstelling verslag } \\
\text { door moeder }\end{array}$ & Totaal \\
\hline Risicocommissie ingesteld & 6 & 6 & 14 & 2 & $28(74 \%)$ \\
\hline Gecombineerde commissie & 1 & 3 & 10 & 1 & $15(39 \%)$ \\
\hline Gecombineerd met de auditcommissie & 1 & 3 & 9 & 1 & $14(37 \%)$ \\
\hline
\end{tabular}

Tabel 5 Permanente educatie Raad van Commissarissen

\begin{tabular}{|l|c|c|c|c|c|}
\hline & Beursgenoteerd & $\begin{array}{c}\text { Beursgenoteerd } \\
\text { buitenland }\end{array}$ & $\begin{array}{c}\text { Niet } \\
\text { beursgenoteerd }\end{array}$ & $\begin{array}{c}\text { Vrijstelling verslag } \\
\text { door moeder }\end{array}$ & \begin{tabular}{c} 
Totaal \\
\hline Permanente educatie genoemd
\end{tabular} \\
\hline Inhoudelijk toegelicht & 5 & 7 & 17 & 3 & $32(84 \%)$ \\
\hline
\end{tabular}


In tabel 5 wordt weergegeven in hoeverre banken melding maken van een programma van permanente educatie voor de RvC. Het merendeel, namelijk 32 (84\%) van de 38 banken maakt melding van een dergelijk programma, waarbij 29 (76\%) banken ingaan op de inhoud. Dit is een verbetering ten opzichte van de conclusie van de Monitoring Commissie Code Banken, die in haar voorrapportage van december 2010 geconstateerd heeft dat de banken betrekkelijk weinig openheid geven over de invulling van de permanente educatie voor leden van de RvB en de RvC. Dit zou voortvarender aangepakt kunnen worden, aldus de commissie.

De onderwerpen die aan de orde komen zijn zeer divers en over het algemeen gelijk aan die genoemd in principe 2.1.8. Het meest frequent worden genoemd: ontwikkelingen binnen de financiële sector, ontwikkelingen binnen de bank, financiële verslaggeving en audit. Een achttal (21\%) banken geeft informatie over de deelname van de commissarissen.

Voorbeelden van onderwerpen die wij hebben aangetroffen, die niet opgenomen zijn in principe 2.1.8. zijn: Maatschappelijk Verantwoord Ondernemen (Bank Nederlandse Gemeenten), informatietechnologie (Rabobank) en het eigen bedrijfsmodel (Triodos Bank). Wij zien Friesland Bank als een best practice aangezien de toelichting verder gaat dan slechts de onderwerpen behandeld in het principe. Tevens is duidelijke informatie opgenomen over de deelname van het programma.

\section{Figuur 2 Best practice toelichting PE programma: Friesland Bank, jaarverslag 2010, p. 38.}

Medio 2010 is Friesland Bank gestart met een programma van permanente educatie voor commissarissen en bestuurders van de bank. Hieraan is door de betrokkenen in 2010 meerdere keren in collectief verband deelgenomen. Daarbij zijn onderwerpen als de Wet op het financieel toezicht, zorgplicht en integriteit aan de orde gekomen. Onder begeleiding van een externe deskundige partij, is ook voor 2011 een programma samengesteld, waaraan alle commissarissen en bestuurders deelnemen. Het collectieve programma is zodanig samengesteld, dat alle onderwerpen uit de bepalingen 2.1.8 en 3.1.3 van de Code Banken aan de orde komen.
Tevens zijn we nagegaan of er informatie wordt gegeven over het feit of de permanente educatie deel uitmaakt van de jaarlijkse evaluatie van de RvC. Acht (21\%) banken geven hier nadere informatie over. Zoals gesteld dient deze zelfevaluatie eens in de drie jaar onder onafhankelijke begeleiding plaats te vinden. Wij hebben onderzocht in hoeverre de onafhankelijke begeleiding van de zelfevaluatie inmiddels is ingevoerd bij de banken, en welke elementen volgens de vermelding in het jaarverslag tijdens de zelfevaluatie zijn besproken.

Van de 38 onderzochte banken hebben 21 (55\%) banken in het jaarverslag een vermelding opgenomen over de onafhankelijke zelfevaluatie van de RvC.? Van deze banken vermelden vijf (13\%) banken dat de zelfevaluatie in 2010 onder onafhankelijke begeleiding heeft plaatsgevonden. Drie (8\%) banken noemen daadwerkelijk de naam van de onafhankelijke begeleider. De zelfevaluatie onder onafhankelijke begeleiding is door acht (21\%) banken wel op de agenda gezet voor de toekomst, waarbij een aantal banken dit reeds voor 2011 heeft ingepland.

Minder mededeelzaam zijn de banken over de elementen die deel hebben uitgemaakt van de zelfevaluatie. Een beperkt aantal banken maakt melding van de betrokkenheid van iedere commissaris, de cultuur binnen de RvC en de relatie met de RvB als besproken thema's. Daarnaast vermeldt een andere bank (BinckBank) dat ook het profiel en de competenties van de $\mathrm{RvC}$ is besproken.

Opvallend is dat de banken zich over de resultaten van de zelfevaluatie weer iets meer mededeelzaam tonen; negen (24\%) banken hebben een inhoudelijke mededeling in het jaarverslag hierover opgenomen. Een verklaring hiervoor kan zijn dat ook de Code Tabaksblat een best practicebepaling bevat met betrekking tot de zelfevaluatie voor de $\mathrm{RvC}$ en dat dit derhalve geen nieuw vereiste is. ${ }^{10}$ Elementen die hierbij onder andere naar voren kwamen zijn de aandacht voor diversiteit in de $\mathrm{RvC}$, de behoefte aan financiële en bancaire kennis en de betrokkenheid bij het remuneratiebeleid en het operationele risico. Bij één bank bleek de eis van onafhankelijkheid van de commissarissen een reden

\section{Tabel 6 Zelfevaluatie Raad van Commissarissen}

\begin{tabular}{|l|c|c|c|c|c|}
\hline & $\begin{array}{c}\text { Beurs- } \\
\text { genoteerd }\end{array}$ & $\begin{array}{c}\text { Beursgenoteerd } \\
\text { buitenland }\end{array}$ & $\begin{array}{c}\text { Niet } \\
\text { beursgenoteerd }\end{array}$ & $\begin{array}{c}\text { Vrijstelling verslag } \\
\text { door moeder }\end{array}$ & \multicolumn{1}{|c|}{ Totaal } \\
\hline $\begin{array}{l}\text { Vermelding van het onderwerp onafhankelijke } \\
\text { begeleiding }\end{array}$ & 4 & 4 & 13 & 0 & 21 (55\%) \\
\hline $\begin{array}{l}\text { Expliciete vermelding dat onafhankelijke } \\
\text { begeleiding heeft plaatsgevonden }\end{array}$ & 2 & 0 & 3 & 0 & $5(13 \%)$ \\
\hline Expliciete vermelding van onafhankelijke begeleider & 1 & 0 & 2 & 0 & 3 (8\%) \\
\hline
\end{tabular}


voor een commissaris om uit de RvC te stappen. BNG neemt duidelijke informatie op over wie de onafhankelijke begeleiding uitvoert en over de uitkomsten van de evaluatie (zie figuur 3).

\section{Figuur 3 Best practice toelichting evaluatie onder onafhankelijke begeleiding: BNG, jaarverslag 2010, p. 11.}

\section{In 2010 heeft de jaarlijkse evaluatie door de Raad van Commissarissen van zijn eigen functioneren plaatsgevonden onder onafhankelijke begeleiding van de heer H.E. van Wijk (Van Wijk Advies, voor Bestuur en Toezicht). De schriftelijke rapportage van de heer Van Wijk is op 7 januari 2011 door hem toegelicht in de raad en door de raad besproken. De beschikbaarheid en bereikbaarheid van commissarissen ten behoeve van vergaderingen van de raad en van commissies van de raad gaf geen aanleiding tot het maken van opmerkingen. De heer Van Wijk heeft geconcludeerd dat de raad goed functioneert, maar dat er enkele punten van aandacht zijn, zoals de borging van de aanwezigheid van voldoende financiële kennis in de raad op lange termijn, de diversiteit naar leeftijd en het belang van permanente educatie op individueel vlak. De raad deelt de conclusies van de heer Van Wijk en zal hieraan in 2011 een vervolg geven.}

\subsection{Raad van Bestuur}

In tabel 7 wordt weergegeven in hoeverre banken melding maken van een programma van permanente educatie voor de $\mathrm{RvB}$; tevens is aangegeven welke onderwerpen tijdens de permanente educatie aan de orde zijn geweest (principes 3.1.3 en 3.1.8). Het geven van deze informatie in het jaarverslag is een expliciete vereiste van de Code Banken. 30 (79\%) van de 38 banken maken melding van een dergelijk programma. Dit zijn er twee minder vergeleken met het aantal banken dat informatie geeft over de RvC. Dit is bijzonder, aangezien zoals opgemerkt de informatieverstrekking betreffende de permanente educatie van bestuurders een expliciete vereiste is. Vervolgens gaan 26 (68\%) banken in op de inhoud. De onderwerpen die aan de orde komen zijn zeer divers en vergelijkbaar met die van de commissarissen, het meest frequent worden genoemd ontwikkelingen binnen de financiële sector, ontwikkelingen binnen de bank, financiële verslaggeving en audit. Uit de jaarverslagen volgt dat er in 21 (55\%) gevallen sprake is van een gecombineerd programma met dat van de RvC. Een zestal (16\%) banken geeft informatie over de deelname van de leden van de RvB. In vergelijking met de $\mathrm{RvC}$ wordt minder informatie verstrekt.

De Code Banken verlangt dat ieder lid van de RvB van een bank een moreel-ethische verklaring ondertekent. Wij hebben onderzocht of de banken melding maken dat deze verklaring is ondertekend, of de verklaring is aangepast zoals de Code Banken toestaat, en zo ja, wat de aanpassing inhoudt.

Vijf (13\%) van de onderzochte banken hebben niet gerapporteerd over de ondertekening van de moreel-ethische verklaring. Van deze vijf banken hebben twee banken een buitenlandse moeder. De mogelijkheid bestaat echter dat de desbetreffende bestuurders de verklaring wel hebben ondertekend, maar dat hierover niet is gerapporteerd in het jaarverslag.

De verklaring heeft bij de banken stof tot nadenken opgeleverd. Zo hebben elf (29\%) banken gemeld dat zij de verklaring hebben aangepast. Een groot aantal banken heeft de term 'bankier' vervangen door '(statutair) bestuurder van (naam bank)' of 'directielid van (naam bank)'. Dit is mogelijk ingegeven door de behoefte om de term 'bankier' nader te preciseren, maar wellicht hebben juridische overwegingen met betrekking tot (beperking van de) bestuurdersaansprakelijkheid hier ook een rol gespeeld.

Een voorbeeld van een RvB die bewust de verklaring heeft aangepast naar zijn specifieke situatie is, is de RvB van AEGON Bank. De leden van de RvB hebben de verklaring gepersonaliseerd, verder aangescherpt, en een onderverdeling gemaakt in een persoonlijke verklaring en een persoonlijke garantie. Daarbij wordt allereerst gegarandeerd dat het desbetreffende RvB-lid zich gedraagt naar de geldende wet- en regelgeving, reglementen, gedragscodes, interne richtlijnen, een Code of Conduct, instructies en normen en waarden. Daarnaast garandeert elk RvB-lid dat hij zich ook conform de verklaring zal gedragen indien hij is geschorst danwel op non-actief is gesteld door of namens de algemene vergadering van aandeelhouders of de $\mathrm{RvC}$ van AEGON Bank N.V. Hier worden met andere woorden de verplichtingen voortvloeiend uit de ondertekening van de verklaring doorgetrokken naar de toekomst, naar een periode ná het dienstverband bij de bank.

Tabel 7 Permanente educatie Raad van Bestuur

\begin{tabular}{|l|c|c|c|c|c|}
\hline & $\begin{array}{c}\text { Beurs- } \\
\text { genoteerd }\end{array}$ & $\begin{array}{c}\text { Beursgenoteerd } \\
\text { buitenland }\end{array}$ & $\begin{array}{c}\text { Niet } \\
\text { beursgenoteerd }\end{array}$ & $\begin{array}{c}\text { Vrijstelling verslag } \\
\text { door moeder }\end{array}$ & Totaal \\
\hline Permanente educatie genoemd & 4 & 7 & 17 & 2 & $30(79 \%)$ \\
\hline Inhoudelijk toegelicht & 4 & 5 & 15 & 2 & $26(68 \%)$ \\
\hline Combinatie met Raad van Commissarissen & 3 & 3 & 13 & 2 & $21(55 \%)$ \\
\hline
\end{tabular}


Figuur 4 Best practice Moreel-ethische verklaring: AEGON Bank, website.

\section{MOREEL_ETHISCHE VERKI_ARING BANKBESTUURDERS}

Ik, Eire Franciscus Mathias Rutten, geboeen te Ons op 5 juni 1962.

Verklas hierbi ovetcenkoenstig de principes van de Code Banken van de Nederlandse Veteniging van Banken, in bet biprondet peincipe 3.2.3, dat ik te allen tijde:

- mijn functie als statutair bestuurder van AEGON Bank N.V., een naumloxe vennootschap, stanutair gevestigd te Utrecht, integer en zotgouldig zal uitoefenen.

- een zocgruldige afwoging mak tussen alle belangen die bij AEGON Bank N.V, spelen, wastonder te verstaan maar nict limitatief de belangen van de klanten, de aanderlhooders, de wetknemess van AEGON Bank N.V, de vennootschap AEGON Bank N.V. zelf en de samenleving wastin AEGON Bank N.V. opereert. It stel in die afweging het belang van de klant central en zal de klant zo goed mogclik inlichten, warbij ak mija bevoegdheden als statutair bestuurder conform de wet, doeloenschnjining en statuten van AEGON Bank N.V. in acht boud.

- mij open en toetsbaar opstel als statutair bestuurder van AEGON Bank N.V.

- mijn verantwoordelijkheid als statutair bestuurdez van AEGON Bank N.V, voor de samenleving ken.

- mij inspan om het vertrouwen in AEGON Bank N.V. specifiek en het bankweren in het algemeen te behouden en te bevorderen.

- mij inspan om het betoep van bankier in ete te houden.

Verder ganndeer ik dat ike

- miij gedrasg naar de geldende wet. en regelgeving de reglementen en de grdnagcodes, AEGONs Code of Conduct en AEGON richtlipen, instructies en normen en warden die op mil als bestuarder van AEGON Bank N.V. van toepassing zijn.

- geheim boud wat mif is toevertround.

- geen misbruik makk van mijn bancaire kennis noch van de kennis die ik (in wellke boedanigheid dan ook) op doe bili AEGON.

- mij ook conform deze Moreel Exhische Verklaring zal gedragen indien ik ben geschoest danwel op non-actief ben gesteld doot of namens de algemene vergadering van andeclhooders of de aad van coenmissarisen van AEGON Bank N.V.

Op deze verklaring is Nederlands recht van torpassing

Ondertekend in rweevood te 's-Gravenhage op 1 november 2010.

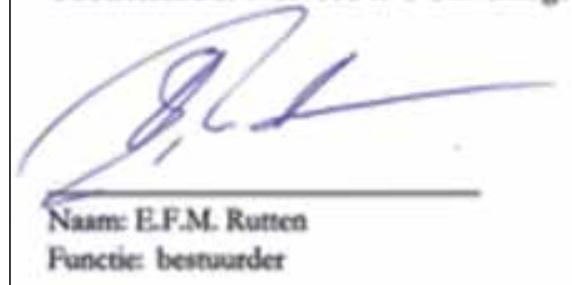

Wij hebben bij veel banken een melding aangetroffen met betrekking tot het uitrollen van de verklaring onder het personeel. Daarbij wordt verwacht dat de medewerkers periodiek de verklaring opnieuw ondertekenen, en dat van nieuwe medewerkers bij ondertekening van hun arbeidsovereenkomst ook de ondertekening van de verklaring wordt verlangd.

\subsection{Risicomanagement}

Zoals eerder beschreven gaat de Code gedetailleerd in op het Product Goedkeuringsproces van nieuw ontwikkelde producten. Uit tabel 8 blijkt dat $31(82 \%)$ banken daadwerkelijk informatie verschaffen over het Product Goedkeuringsproces. Van deze groep geven twintig (53\%) banken een inhoudelijke toelichting van het proces. Deze 
Tabel 8 Product Goedkeuringsproces

\begin{tabular}{|l|c|c|c|c|c|}
\hline & $\begin{array}{c}\text { Beurs- } \\
\text { genoteerd }\end{array}$ & $\begin{array}{c}\text { Beursgenoteerd } \\
\text { buitenland }\end{array}$ & $\begin{array}{c}\text { Niet beurs- } \\
\text { genoteerd }\end{array}$ & $\begin{array}{c}\text { Vrijstelling verslag } \\
\text { door moeder }\end{array}$ & Totaal \\
\hline Product Goedkeuringsproces ingesteld & 6 & 6 & 17 & 2 & $31(82 \%)$ \\
\hline Geen Product Goedkeuringsproces ingesteld & 0 & 0 & 1 & 0 & $1(3 \%)$ \\
\hline Niet toegelicht of proces ingesteld is & 0 & 2 & 2 & 2 & $6(16 \%)$ \\
\hline Is proces inhoudelijk toegelicht & 6 & 2 & 10 & 2 & $20(53 \%)$ \\
\hline
\end{tabular}

toelichting bestaat veelal uit de elementen genoemd in de Code Banken, namelijk risicoanalyse en zorgplicht jegens de klant. Zeven (18\%) banken noemen ook andere elementen die onderdeel uitmaken van het proces, waaronder compliance met wet- en regelgeving. Een voorbeeld is de inhoudelijke toelichting van Van Lanschot die een gedetailleerde toelichting opneemt van het proces (zie figuur 5). Een niet-beursgenoteerde bank geeft expliciet aan geen Product Goedkeuringsproces ingesteld te hebben aangezien zij geen eigen producten op de markt brengt.

Bij zestien (42\%) banken wordt informatie verstrekt over de controle door de interne auditors. Bij negen (24\%) banken wordt expliciet vermeld dat deze functionarissen niet alleen naar de opzet en bestaan hebben gekeken, maar ook

\section{Figuur 5 Best practice Product Goedkeuringsproces: Van Lanschot, jaarverslag 2010, p. 52.}

\footnotetext{
Van Lanschot streeft er naar om alleen producten aan te bieden die passend zijn en toegevoegde waarde hebben voor de client en een juiste prijs-kwaliteitverhouding hebben. Voor nieuwe producten is er een productgoedkeuringsproces, de New Product Approval-procedure (NPAprocedure), zoals beschreven in principe 4.5 van de Code Banken. In de NPAprocedure wordt expliciet aandacht besteed aan het aspect klantzorg. Alle leden van de Product Board hebben in de NPAprocedure een vetorecht met betrekking tot het besluit om een nieuw product te introduceren en moeten voor de introductie tekenen voor hun goedkeuring voor de introductie van een product. Voor bestaande producten kent Van Lanschot de Product Review-procedure. In de Product Review-procedure worden bestaande producten opnieuw doorgelicht, waarbij onder meer aandacht wordt besteed aan klantzorg.

Binnen Van Lanschot is de Product Board verantwoordelijk voor de introductie van nieuwe producten en de review van bestaande producten. In de vergaderingen van de Product Board worden de NPA's, de evaluaties van nieuwe producten (tussen de drie en zes maanden na implementatie van een product wordt een evaluatie gemaakt en voorgelegd aan de Product Board) en Product Reviews besproken. Bij de besluitvorming door de Product Board wordt veel aandacht besteed aan de kwaliteit van de producten. Ook besteedt de Product Board bij de besluitvorming aandacht aan een zorgvuldige en evenwichtige informatieverstrekking aan de cliënt. Van Lanschot streeft er naar dat de productdocumentatie volledig, begrijpelijk en toegankelijk is.
}

naar de werking van het goedkeuringsproces. In acht $(21 \%)$ jaarverslagen wordt gemeld dat de RvB is geïnformeerd over de uitkomsten van deze controle en in vijf gevallen is ook gerapporteerd aan de (risico)commissie van de RvC. Eén bank heeft vermeld dat deze beoordeling heeft geleid tot de opzet van een nieuwe procedure. Alle beursgenoteerde banken hebben toegelicht dat zij een Product Goedkeuringsproces hebben geïmplementeerd, gevolgd door $85 \%$ van de niet-beursgenoteerde banken, $75 \%$ van de in het buitenland genoteerde banken en $50 \%$ van de banken die gebruikmaken van de 403-vrijstelling.

\subsection{Audit}

De Code hecht veel belang aan de interne auditfunctie en veronderstelt dat die altijd is ingesteld door de RvB. Uit tabel 9 blijkt dat ook vrijwel altijd zo te zijn. Eén (3\%) bank heeft niet toegelicht of een interne audit is ingesteld. Bij veel (kleinere) banken is deze afdeling gepositioneerd bij de moedermaatschappij.

Om zo onafhankelijk mogelijk te kunnen functioneren is een directe rapportagelijn van de interne auditors naar de voorzitter van de RvB en de (auditcommissie van de) RvC van groot belang. Uit ons onderzoek blijkt dat deze rapportagelijnen (nog) niet bij alle banken bestaan.

Informatie over het jaarlijkse tripartiete overleg tussen de interne auditfunctie, DNB en de externe accountants wordt in $21(55 \%)$ jaarverslagen verstrekt. Hier valt op dat de niet-beursgenoteerde banken meer informatie opnemen dan de beursgenoteerde banken. De wijze van

\section{Figuur 6 Best practice tripartiet overleg: Nederlandse Waterschaps Bank, jaarverslag 2010, p. 38.}

Het hoofd van de interne auditfunctie rapporteert aan de voorzitter van de directie en heeft tevens een rapportagelijn naar de voorzitter van de Auditen Risicocommissie. Het hoofd woont, evenals de externe accountant, de bijeenkomsten van de Audit- en Risicocommissie bij. Met ingang van 2010 vinden bijeenkomsten plaats met de interne en externe accountant en de prudentieel toezichthouder (De Nederlandsche Bank). Tijdens dit overleg vindt uitwisseling van inzichten plaats en de planning van haar activiteiten. Ook de afdeling Risk Management van de NWB Bank is vertegenwoordigd bij deze bijeenkomsten. 
Tabel 9 Internal Audit

\begin{tabular}{|c|c|c|c|c|c|}
\hline & $\begin{array}{l}\text { Beurs- } \\
\text { genoteerd }\end{array}$ & $\begin{array}{l}\text { Beursgenoteerd } \\
\text { buitenland }\end{array}$ & $\begin{array}{l}\text { Niet beurs- } \\
\text { genoteerd }\end{array}$ & $\begin{array}{l}\text { Vrijstelling verslag } \\
\text { door moeder }\end{array}$ & Totaal \\
\hline IAD Ingesteld & 6 & 8 & 19 & 4 & $37(97 \%)$ \\
\hline Niet toegelicht & 0 & 0 & 1 & 0 & $1(3 \%)$ \\
\hline $\begin{array}{l}\text { Vermelding dat het hoofd IAD rapporteert aan de } \\
\text { voorzitter van de RvB }\end{array}$ & 6 & 6 & 16 & 2 & $30(79 \%)$ \\
\hline $\begin{array}{l}\text { Vermelding dat het hoofd IAD een rapportagelijn heeft } \\
\text { naar de voorzitter van de auditcommissie en/of de RvC }\end{array}$ & 6 & 7 & 18 & 3 & $34(89 \%)$ \\
\hline Vermelding tripartiete overleg & 3 & 4 & 14 & 0 & $21(55 \%)$ \\
\hline
\end{tabular}

informatieverstrekking van de Nederlandse Waterschapsbank zien wij als een best practice aangezien de bank een gedetailleerde toelichting geeft ten aanzien van het tripartiete overleg.

\section{Conclusies en aanbevelingen}

In de jaarverslagen van de banken over 2010 dient voor het eerst verantwoording te worden afgelegd over de naleving van de principes van de Code Banken. Onduidelijk is hoe ver deze verantwoording dient te gaan. Is het voldoende om te stellen 'ik pas toe' of moet een bank verder gaan en per principe aangeven op welke wijze deze wordt nageleefd. In ons onderzoek van 38 banken met een vergunning in Nederland zijn we ingegaan op de vraag hoe de banken de verantwoording in de praktijk hebben vormgegeven. Een aantal banken met een vergunning is niet in het onderzoek meegenomen, aangezien de jaarrapporten niet beschikbaar waren op 30 juni 2011 op de website van de onderneming, of op de website van de Kamer van Koophandel.

De belangrijkste bevindingen met betrekking tot de informatieverschaffing over de naleving van de Code Banken zijn:

- De verslaggeving van de in Nederland beursgenoteerde banken lijkt kwalitatief het best, gevolgd door de banken genoteerd in het buitenland en de niet-beursgenoteerde banken.

- 21 (55\%) banken maken expliciet melding van de naleving van de Code Banken. Drie (8\%) banken geven aan alle principes te volgen. Achttien (47\%) banken noemen duidelijk de afwijkingen en lichten deze toe.

- Veertien (37\%) banken doen wel een mededeling, maar maken geen expliciete melding van de naleving. $\mathrm{Zij}$ bespreken de Code Banken en alleen door integraal de tekst te lezen en in sommige gevallen zelf te interpreteren en te concluderen wordt duidelijk welke principes zijn nageleefd. Dit beschouwen wij als minder gebruikersvriendelijke informatie in vergelijking tot de expliciete mededelingen.
- Een drietal (8\%) banken brengt helemaal geen verslag uit. Dit betreft een niet-beursgenoteerde bank gevestigd in Nederland en twee moedermaatschappijen gevestigd in het buitenland van een Nederlandse bank met een vergunning die gebruik maakt van een 403-vrijstelling. Mogelijk zijn deze buitenlandse moedermaatschappijen zich niet bewust dat zij dienen te rapporteren over de Code Banken.

- Twintig (53\%) banken brengen zowel verslag uit over de Code Banken in het jaarverslag als op de website. Van zes (16\%) banken uit deze groep omvat het jaarverslag geen verwijzing, waardoor de informatie geplaatst op de website formeel geen deel uitmaakt van het jaarverslag.

- 28 (74\%) banken hebben een risicocommissie ingesteld. Vijftien (40\%) banken combineren deze commissie met een andere commissie, en dat is in veertien gevallen de auditcommissie. Wij zijn van mening dat het heel goed voorstelbaar is dat de risicocommissie wordt geïntegreerd in de auditcommissie.

- 32 (84\%) banken geven informatie over het programma van permanente educatie van de $\mathrm{RvC}$ en 30 (79\%) banken over het betreffende programma van de RvB. 21 (55\%) banken hebben toegelicht dat beide programma's gecombineerd zijn. Opvallend is dat de informatie omtrent de permanente educatie van de bestuurders niet in alle gevallen wordt gegeven, ondanks het feit dat dit een expliciete verplichting is in de Code Banken. Ook geeft een aantal banken aan om in de toekomst aan de verplichting te gaan voldoen.

- Een toelichting over zelfevaluatie onder onafhankelijke begeleiding hebben wij bij 21 (55\%) banken aangetroffen. De informatie over de inhoud en uitkomsten van de zelfevaluatie is beperkt.

- Van de 38 banken hebben 33 (87\%) melding gemaakt van de moreel-ethische verklaring. Van deze groep hebben elf (29\%) banken de tekst, zoals voorgesteld in de Code Banken, aangepast.

- 31 (82\%) banken maken melding van een Product Goedkeuringsproces. 20 (53\%) banken lichten het proces inhoudelijk toe, waarbij meestal wordt volstaan met het 
noemen van de in de Code Banken genoemde elementen, te weten risicoanalyse en zorgplicht jegens de klant. Zestien (42\%) banken maken melding dat de interne auditfunctie jaarlijks het proces beoordeelt.

- 37 (97\%) banken hebben toegelicht een internal audit afdeling te hebben die onafhankelijk is geplaatst. De rapportagelijn naar de $\mathrm{RvC}$ is niet altijd duidelijk toegelicht. 21 (55\%) banken maakt melding van het tripartiete overleg.

Op basis van deze bevindingen concluderen wij dat de meeste banken uitgebreid rapporteren over de naleving van de Code Banken, mede gezien het feit dat er niet een expliciet vereiste is dat uitgebreid te doen. Wij krijgen het idee dat banken door transparant te willen zijn daadwerkelijk werken aan het terugwinnen van het vertrouwen. Verder zijn wij van mening dat de kwaliteit van de mededeling over de toepassing van de Code Banken beter kan. In sommige gevallen is zelfs na lezing van het jaarverslag en/of website niet duidelijk welke principes zijn toegepast en welke worden toegelicht. Dit zien wij als een gemiste kans. Deze mededeling zien wij namelijk als relevante informatie voor de gebruiker van de jaarrekening.

Wij doen de volgende aanbevelingen:

- De Monitoring Commissie dient guidance te verstrekken over de wijze (plaats, medium en structuur) waarop de banken informatie over de naleving van de Code Banken dienen te publiceren.

- Zorg dat duidelijk is waar de informatie over de Code Banken te vinden is, bij voorkeur in hoofdlijnen in het jaarverslag en meer uitgebreide informatie op de website (bijvoorbeeld een overzicht met alle principes en het feit of deze worden nageleefd). Maak heldere afspraken over de eisen die worden gesteld aan het 'rechtstreeks en permanent toegankelijk' zijn van de informatie op de website. Wellicht kan de Monitoring Commissie hieraan een nadere invulling geven.
- De informatie over de permanente educatie kan uitgebreider, met name informatie over de behandelde onderwerpen en het feit of de bestuurders en commissarissen aan hun verplichtingen voldoen.

- De informatie over de zelfevaluatie van de RvC kan uitgebreider, met name de uitkomsten van de evaluatie en de eventuele maatregelen zijn interessant.

- De moreel-ethische verklaring heeft nu vooral betrekking op het verleden, wij bevelen aan om de reikwijdte naar de toekomst uit te breiden.

Ten slotte blijkt dat de huidige praktijk van de verslaggeving over de Code Banken nogal uiteen loopt, maar wij zijn wel van mening dat de banken het onderwerp serieus hebben opgepakt. In ons artikel maken wij ten aanzien van een aantal onderwerpen melding van 'best practices'. De banken zijn zelf aan zet om hier in de toekomst nog verder invulling aan te geven.

Prof. dr. A. de Bos RA is parttime hoogleraar Bedrijfseconomie aan de Erasmus Universiteit Faculteit der Rechtsgeleerdheid en is als partner verbonden aan Ernst \& Young.

Drs. H.W. Edelman RA is als manager werkzaam bij Ernst \& Young en verricht naast zijn werkzaamheden in de controlepraktijk onderzoek op het gebied van corporate governance.

Mr. M.E.P.A.R. Jans-van Wieringen is vanuit Jans Juridisch Advies werkzaam als jurist op de gebieden governance, ondernemingsrecht en compliance, en is daarnaast als Senior Associate verbonden aan notariskantoor DeHeng Civil Code N.V.

J. Scheffe RA is vaktechnisch medewerker

Beroepsontwikkeling en -beleid, Capital Markets van de NBA (voorheen het Koninklijk NIVRA). 
I. Op dit moment spreekt Bos over 'best practices', in de Code Banken zijn de 'best practices' in een later stadium verheven tot principes.

2 Wij merken op dat, in tegenstelling tot de Nederlandse Corporate Governance Code, de principes in de Code Banken niet verder zijn uitgewerkt in best practice bepalingen. Dit betekent dat aan de banken zelf wordt overgelaten hoe deze principes verder vorm te geven.

3 Zie Preambule Code Banken, p. 2, derde punt. 4. Zie Preambule Code Banken, p. 2, vierde punt. 5 Zie Code Banken, toelichting op principe 2.1.1 6 Wij willen hier vermelden dat de informatie niet in alle gevallen lijkt te voldoen aan de eis 'recht- streeks en permanent toegankelijk'. Omdat deze eis niet gedetailleerder is uitgewerkt in het Besluit, betrekken wij als sprake is van een verwijzing in het jaarverslag de op de website beschikbare informatie in ons onderzoek.

7 Zes (16\%) banken bezitten een beursnotering in Nederland en één (3\%) bank maakt gebruik van de vrijstelling in artikel 403 boek 2 BW en maakt onderdeel uit van een groepsmaatschappij die een beursnotering in Nederland heeft.

8 Uit ons onderzoek blijkt overigens dat banken het 'pas toe of leg uit'-beginsel per principe niet altijd eenduidig toepassen. Zo wordt de mededeling dat de bank in 2011 zal voldoen aan een principe door de ene bank wel en door de andere bank niet beschouwd als een afwijking. Ook in het geval een bank rapporteert een principe gedeeltelijk te volgen, wordt dit soms wel en soms niet als 'volledige' afwijking gerapporteerd. 2. Deze 21 banken bestaan uit: vier (67\%) van de in Nederland beursgenoteerde, vier (50\%) van de in het buitenland genoteerde, dertien (65\%) van de niet-beursgenoteerde banken uitgedrukt in percentages op basis van de deelpopulaties. 10 Zie Nederlandse Corporate Governance Code Best Practice III.1.7.

\section{Literatuur}

\begin{tabular}{|c|c|c|}
\hline Advie & banken, dd. 24 maal & r 2010, zie: http://www. \\
\hline l van vertrouwen, zie: www.nvb.nl & FM/2009/3678 M & commissiecodebanken.nl. \\
\hline AFM & n (2010), & NIVRA (2009), brief aan NVB, d.d. 20 mei \\
\hline i 2009 & ant en auditcommissie, Maan & 2009 \\
\hline Annink, H.M., F. Van Proosdij en A. & ijfseconomie, vol. & 2009), Reactie op rapport \\
\hline hg bij & & 7 april \\
\hline nken, Maandblad voor Acc & accountant in & 2009. \\
\hline drijfseconomie, vol. 80, no. 10, pp. 477-486. & teem: waarschuwen of & orbreek de stilte bij \\
\hline (2009), Brief ac & bij banken?, Maandblad & 11. \\
\hline e Kamer der Staten-Generaal, d.d. 10 & in Bedrijfseconomie, vol. 84, & fwijkt, \\
\hline Diekman, P. (2010), Vertrouwen in banken: & anciën (2009), Het & p. $14-15$. \\
\hline ige bedreigingen en ankerpunten, Maandblad & Minis & \\
\hline $\begin{array}{l}\text { ccountancy en Bedrijfseconomie, vol. 84, } \\
\text { p. 123-132. }\end{array}$ & $\begin{array}{l}\text { nieuwsbericht } 9 \text { september 2009, zie: www. } \\
\text { rijksoverheid.nl }\end{array}$ & eede \\
\hline Nederlandsche Bank brief aan Minister & - Monitoring Commissie Code Banken (2010a), & r, vergaderjaar 2009-2010, 31 980, \\
\hline ager, J.C. (2010), brief aan Voo & coml & ) Veel schuldig \\
\hline Omorder Ctoton Conornol & itoring Commicoin Codd & S Maas, d.d. \\
\hline & & \\
\hline
\end{tabular}

\section{Wet- en regelgeving}

- Boek 2 Titel 9 Burgerlijk Wetboek

- Wet op het financieel toezicht

- Besluit vaststelling nadere voorschriften inhoud jaarverslagen banken

- Nota van toelichting bij ‘Besluit vaststelling nadere voorschriften inhoud jaarverslagen banken’

- Monitoring Commissie Corporate Governance Code, De Nederlandse corporate governance code: beginselen van deugdelijk ondernemingsbestuur en best practice bepalingen, zie www.corpgov.nl

- NVB, Code Banken, zie: www.nvb.nl 


\section{Bijlage 1 onderzoekspopulatie}

\begin{tabular}{|l|l|}
\hline 1. & ABN AMRO Bank N.V. \\
\hline 2. & Aegon Bank N.V. \\
\hline 3. & Akbank N.V. \\
\hline 4. & Amsterdam Trade Bank N.V. \\
\hline 5. & Anadolubank Nederland N.V. \\
\hline 6. & Anthos Bank B.V. \\
\hline 7. & ASR Bank \\
\hline 8. & Bank of Tokyo-Mitsubishi UFJ (Holland) N.V. \\
\hline 9. & Bank Ten Cate \& Cie N.V. \\
\hline 10. & BinckBank N.V. \\
\hline 11. & BNP Paribas Bank N.V. \\
\hline 12. & Credit Europe Bank N.V. \\
\hline 13. & Delta Lloyd Bank N.V. \\
\hline 14. & Demir-Halk Bank Nederland N.V. \\
\hline 15. & Deutsche Bank Nederland NV \\
\hline 16. & Economy Bank \\
\hline 17. & F. van Lanschot Bankiers N.V. \\
\hline 18. & Friesland Bank N.V. \\
\hline 19. & GarantiBank International N.V. \\
\hline
\end{tabular}

\begin{tabular}{|l|l|}
\hline 20. & GE Artesia Bank \\
\hline 21. & Hof Hoorneman Bankiers N.V. (voorheen VPV Bankiers N.V.) \\
\hline 22. & ING Bank N.V. \\
\hline 23. & Interbank N.V. \\
\hline 24. & KAS BANK N.V. \\
\hline 25. & Lease Plan Corporation N.V. \\
\hline 26. & Lombard Odier Darier Hentsch \& Cie (Nederland) N.V. \\
\hline 27. & N.V. Bank Nederlandse Gemeenten \\
\hline 28. & N.V. Bank voor de Bouwnijverheid \\
\hline 29. & Nederlandse Financierings-Maatschappij voor Ontwikkelingslanden N.V. \\
\hline 30. & NIBC Bank N.V. \\
\hline 31. & NWBB Bank \\
\hline 32. & Oyens \& Van Eeghen N.V. \\
\hline 33. & Rabobank Nederland \\
\hline 34. & SNS Bank N.V. \\
\hline 35. & Staalbankiers \\
\hline 36. & The Royal Bank of Scotland N.V. \\
\hline 37. & Triodos Bank N.V. \\
\hline 38. & UBS Bank Netherlands B.V. \\
\hline
\end{tabular}


Bijlage 2 afwijkingen van banken die expliciet rapporteren

\begin{tabular}{|c|c|c|c|}
\hline Paragraaf & Principe & Onderwerp & Aantal afwijkingen \\
\hline RvC & 2.1 .1 & Samenstelling & 1 \\
\hline RvC & 2.1 .4 & Deskundigheid en profielschets & 1 \\
\hline $\operatorname{RvC}$ & 2.1 .8 & Programma van permanente educatie & 2 \\
\hline RvC & 2.1 .9 & Beoordeling effectiviteit van programma van permanente educatie & 2 \\
\hline RvC & 2.1.10 & Evaluatie onder onafhankelijke begeleiding & 3 \\
\hline RvC & 2.2 .1 & Risicocommissie & 2 \\
\hline RvC & 2.2 .2 & Competentie en ervaringseisen risicocommissie & 1 \\
\hline RvB & 3.1 .1 & Samenstelling & 1 \\
\hline RvB & 3.1 .3 & Programma van permanente educatie & 1 \\
\hline RvB & 3.2 .2 & Zorgplicht klant & 1 \\
\hline RvB & 3.2 .3 & Moreel-ethische verklaring & 1 \\
\hline RvB & 3.2 .4 & Doorvertalen moreel-ethische verklaring naar principes & 4 \\
\hline Risico Management & 4.1 & Verantwoordelijkheid Risicobereidheid & 2 \\
\hline Risico Management & 4.2 & Toezicht RvC op risicobeleid & 1 \\
\hline Risico Management & 4.5 & Product Goedkeuringsproces & 3 \\
\hline Audit & 5.2 & Onafhankelijke positie & 1 \\
\hline Beloningsbeleid & 6.2 .1 & Toezicht RvC op beloningsbeleid & 2 \\
\hline Beloningsbeleid & 6.2 .2 & Toezicht RvC specifiek op variabele beloningen & 1 \\
\hline Beloningsbeleid & 6.3 .1 & Totale inkomen RvB & 2 \\
\hline Beloningsbeleid & 6.3 .2 & Ontslagvergoeding RvB & 3 \\
\hline Beloningsbeleid & 6.3 .3 & Variabele beloning RvB & 3 \\
\hline Beloningsbeleid & 6.3 .4 & Toekennen aandelen aan RvB & 2 \\
\hline Beloningsbeleid & 6.4 .1 & Variabele beloning: lange termijn doelstellingen & 2 \\
\hline Beloningsbeleid & 6.4 .3 & Variabele beloning: prestatiecriteria & 3 \\
\hline Beloningsbeleid & 6.4 .4 & Variabele beloning: correctie voor beoordelen op basis van financiële prestatiecriteria & 2 \\
\hline Totaal & & & 47 \\
\hline
\end{tabular}

